\title{
Earnings Management and Audit Quality in Europe: Evidence from the Private Client Segment Market
}

\author{
Brenda Van Tendeloo ${ }^{\#}$ \\ University of Antwerp \\ Ann Vanstraelen \\ University of Antwerp and Maastricht University
}

May 2005

\begin{abstract}
This paper examines audit quality in private firms across different European countries. Prior research (e.g. Becker et al., 1998; Francis et al., 1999) has shown that audit quality provides a constraint on earnings management for public firms. We investigate whether audit quality differentiation also holds in private firms, constituting the majority of the EU economy and the EU market for audit services. This is an empirical question given that opposing arguments for (and against) the existence of a Big 4 audit quality difference between public and private firms can be given. Moreover, we question whether this audit quality difference, if any, is influenced by institutional factors. Using data on private firms of six European countries, this study provides evidence that, after controlling for self-selection, audit quality differentiation between Big 4 and non-Big 4 audit firms also exists in the private client segment market. However, we do not find support for an audit quality difference between second-tier and small audit firms. Consistent with prior research, we find that private companies domiciled in countries with a stronger investor protection engage less in earnings management. In addition, our results suggest that audit quality and investor protection are substitutes in constraining earnings management in private firms, in the sense that the Big 4 audit quality effect attenuates when investor protection is stronger.
\end{abstract}

${ }^{\#}$ Corresponding Author: Brenda Van Tendeloo, Universiteit Antwerpen, Faculty of Applied Economics, Prinsstraat 13, B-2000 Antwerpen, Belgium. E-mail: brenda.vantendeloo@ua.ac.be 


\section{Introduction}

Audit quality differentiation between Big $4^{1}$ and non-Big 4 audit firms has received considerable attention in prior research. However, prior studies on audit quality differentiation have almost exclusively focused on public firms. We investigate whether audit quality differentiation also exists in the private client segment market. From an economic perspective, there are opposing arguments for (and against) expecting audit quality differentiation to hold in the private client segment market. On the one hand, it could be argued that, relying on internationally recognized brand names, Big 4 firms have an incentive to provide a uniform level of audit quality across different market segments and hence would be inclined to supply high quality audits also in privately held client firms. On the other hand, one could argue that Big 4 auditors would be more lenient for private client firms compared to public client firms due to the lower risk of litigation for private firms. Indeed, Dye (1993) shows that a less litigious setting should weaken the extent to which the auditor's wealth serves as a bond for audit quality. Hence, it is an empirical question whether reputation concerns of Big 4 auditors are sufficiently strong to control the higher moral hazard risk in the private client segment market ${ }^{2}$.

We use the extent in which earnings management is constrained as a measure of audit quality differentiation. Prior research (e.g. Becker et al., 1998; Francis et al., 1999) has shown that Big 4 auditors provide a significant constraint on earnings management for public firms. We investigate whether this also holds for private firms. In particular, we focus on private firms across different European countries. Private firms constitute the majority of the EU economy and of the EU market for audit services. The Fourth EU Directive requires that private EU firms that exceed certain size criteria have their financial statements audited. Following Chaney et al. (2004), investigating self-selection of auditors and audit pricing in UK private firms, we control for self-selection bias. Self-selection can indeed confound the results if auditor choice (Big 4/non-Big 4) is endogenous in the earnings management regressions.

\footnotetext{
${ }^{1}$ For convenience we use the term Big 4 auditor to identify the large international audit firm networks. Some of the studies we refer to were conducted before the mergers resulted into a reduction to 4 international audit networks.

2 This line of reasoning is similar to Khurana and Rama (2004) investigating audit quality differentiation for listed firms in ASEAN countries where litigation exposure is low or nonexistent.
} 
Our sample consists of all private firms in six EU-countries during the period 1998-2002 that are required by law to have their financial statements audited and for which both financial data and audit firm data were available in the Amadeus database $^{3}$. The choice for studying more than one EU country is motivated by the fact that it offers the opportunity to examine to what extent audit quality differentiation, if any, in the private client segment market is uniform across countries. Prior research has shown that Big 4 auditors do not appear to be equally conservative for public firms in all audit environments and is a function of the level of investor protection (see Francis and Wang, 2003; Maijoor and Vanstraelen, 2004). Hence, we investigate whether stronger investor protection attenuates the higher auditor moral hazard risk for private client firms.

In most continental European countries the private client audit market is less concentrated compared to for instance the US and the UK. In these less concentrated markets, it may be appropriate to further subdivide the non-Big 4 audit firms in the so-called second-tier audit firms and small audit firms. Therefore, we also investigate whether there is audit quality differentiation between second-tier audit firms and small audit firms for private client firms.

Our results suggest that audit quality differentiation also exists in the private client segment market. Consistent with prior research, we find that private companies domiciled in countries with a stronger investor protection engage less in earnings management. In addition, audit quality and investor protection appear to be substitutes in constraining earnings management in private firms, in the sense that the Big 4 audit quality effect attenuates in countries with stronger investor protection. Finally, our results do not appear to support a significant audit quality difference between secondtier audit firms and small audit firms.

The remainder of this paper is organised as follows. In section 2, we review the relevant literature and provide the theoretical background of the paper. In section 3, we formulate the research hypotheses. Section 4 describes the research design. The results of the study are presented in section 5. Finally, in section 6, we summarize our results, discuss the implications and limitations of our analysis and give suggestions for further research.

\footnotetext{
${ }^{3}$ Amadeus is a database containing financial data of public and private firms in Europe. Due to data limitations, we could only include 6 out of the 15 EU member states in 2002.
} 


\section{Previous literature}

2.1 Earnings management in private firms

While numerous studies have investigated earnings quality and its determinants among public firms, only a few studies have considered earnings management in private firms (see Beatty and Harris, 1998; Beatty, Ke and Petroni 2002; Coppens and Peek, 2005; Burgstahler, Hail and Leuz, 2004). Given the unique attributes of private firms as opposed to public firms and the fact that private firms constitute the majority of the EU economy and of the EU market for audit services, this research seems warranted.

Private companies are more closely held, have greater managerial ownership, major capital providers often have insider access to corporate information and capital providers take a more active role in management. Moreover, their financial statements are not widely distributed to the public and are more likely to be influenced by tax objectives (Ball and Shivakumar, 2005). Due to the different economic function of financial reporting in private firms, there is less demand for shareholder oriented earnings quality attributes such as earnings conservatism. As a result, private firms incorporate losses less timely than public firms, as shown by Ball and Shivakumar (2005) for U.K. firms.

The main users of private firms' financial statements are stakeholders other than equity investors, such as employees, bankers, tax authorities, customers, suppliers and the government. To protect the interests of these stakeholders, private European companies that exceed certain size criteria ${ }^{4}$ are required to have their financial statements audited. To the extent that managers want to "mislead some stakeholders about the underlying economic performance of the company or to influence contractual outcomes that depend on reported accounting numbers" (Healy and Wahlen, 1999, p. 368) earnings will also be managed in private firms ${ }^{5}$.

On the one hand, one could expect private firms to engage more in earnings management than public firms. First, because privately held firms have more

\footnotetext{
${ }^{4}$ In accordance with the Fourth Council Directive (78/660/EEC) of 25 July 1978 only small companies are exempted from a statutory audit. According to this Directive small companies are companies that do not exceed more than one of following criteria: a) Average number of employees: 50; b) Balance sheet total: 3125000 EUR; c) Annual net turnover: 6250000 EUR. Companies with more than 100 employees are always considered as large companies.

${ }^{5}$ While the exercised discretion in reporting earnings can also be used to signal private information and reduce information asymmetry (e.g. Subramanyam, 1996), we assume earnings are managed for opportunistic reasons to mislead some stakeholders or influence contractual outcomes, following the definition of Healy and Wahlen (1999).
} 
concentrated ownership and major capital providers often have insider access to corporate information, earnings wouldn't have to be as informative about economic performance. While shareholders of public firms are only prepared to supply the company with capital at low cost if the financial information that is provided to them is perceived as high quality, private firms have less incentives to report financial information that reflects economic performance in order to acquire financing at low cost. Accordingly, private firms face less of a trade-off if they manage earnings to minimize taxes or determine shareholder compensations but hereby make earnings less informative (Burgstahler et al. 2004). Second, bank financing is usually a major source of finance in privately held companies, resulting in agency conflicts between bankers and owners and bankers and management (VanderBauwhede and Willekens, 2002), which could also create earnings management incentives.

On the other hand, more concentrated ownership and hence lower agency problems would create less incentives to hide true performance by managing earnings. Certain capital market motivations to manage earnings could be expected to be stronger for public firms, leading private firms to engage less in earnings management. Further, since small investors in stock markets are expected to rely more on earnings targets than sophisticated investors such as banks, public firms may be more likely to engage in earnings management to meet those targets (Beatty et al., 2002). Consistent with these arguments, Beatty and Harris (1999) and Beatty, Ke and Petroni (2002) show that earnings management is more prevalent among public banks than among private banks. Burgstahler et al. (2004), however, show that these findings do not generalize outside the highly regulated U.S. banking sector, and find that earnings management is more pervasive in private firms.

Similar to public firms, earnings management in private firms deprives the users of financial statements of obtaining reliable information. The task of the statutory auditor is to protect stakeholders' interests. Hence, it is questioned to what extent audit quality constitutes a constraint on earnings management in private firms.

\subsection{Audit quality in private firms}

All large European companies are required to have their financial statements audited. The statutory auditor is expected to provide different stakeholders of the company assurance concerning the accuracy of the financial statements, the nonexistence of fraud and the going concern status. Audit quality depends on (1) the 
probability that material misstatements and signals of financial distress are discovered and (2) the probability that the auditor will report these misstatements and signals (DeAngelo, 1981). While the technical capability of auditors or the probability that the auditor will discover material misstatements and going concern breaches is usually assumed to be constant across different auditors, audit quality is assumed to be a function of auditor independence. Litigation and disciplinary sanctions are supposed to ensure auditor independence. Without these enforcement mechanisms, auditors might be tempted to compromise their independence and hence, neglect to constrain earnings management or issue a qualified opinion when necessary (Vander Bauwhede and Willekens, 2004).

Previous studies generally use the dichotomous Big 4/non-Big 4 audit variable to capture audit quality differences. In this respect, larger audit firms are expected to be less likely to perform low-quality audits because these firms have more to lose in terms of clients and audit fees in case of an audit failure (DeAngelo, 1981). Auditor independence is thus considered to relate to the auditor's reputational capital (DeAngelo, 1981). We use the extent in which earnings management is constrained as a measure of audit quality.

A number of studies have shown that Big 8/6/5/4 auditors constitute a constraint on earnings management for public firms (DeFond and Jiambalvo, 1991; DeFond and Jiambalvo, 1993; Becker et al., 1998; Francis et al. 1999; Gore et al., 2001). However, the results of Francis and Wang (2003) and Maijoor and Vanstraelen (2004) suggest that Big 4 auditors are not equally conservative across different audit environments with regard to constraining earnings management in public firms. Given the important differences between public and private firms, influencing both the demand and supply of high quality auditing, it can be questioned whether audit quality differences also hold for private firms.

From an economic perspective, there are opposing arguments for (and against) expecting audit quality differentiation, in terms of larger audit firms providing a larger constraint on earnings management, to hold in the private client segment market. On the one hand, it could be argued that, relying on internationally recognized brand names, Big 4 audit firms have an incentive to provide a uniform level of audit quality across different market segments and hence would be inclined to supply high quality audits also in privately held client firms. 
On the other hand, one could argue that Big 4 auditors would be more lenient for private client firms compared to public client firms due to the lower risk of litigation for private firms. Since financial statements of private firms are not scrutinized as much by investors, financial analysts or regulating authorities of stock exchanges, the probability that an audit failure is detected and the risk of litigation is much lower in privately held companies (Chaney et al., 2004; Vander Bauwhede and Willekens, 2004). Dye (1993) shows that a less litigious setting should weaken the extent to which the auditor's wealth serves as a bond for audit quality. Hence, it is an empirical question whether reputation concerns of Big 4 auditors are sufficiently strong to control the higher moral hazard risk in the private client segment market.

Previous studies concerning this research question have, to our knowledge, only been performed for the Belgian audit market and provide mixed results. Sercu et al. (2002) do not find audit quality differences in the private client segment of the Belgian audit market based on individual financial statements. Based on a sample of consolidated financial statements, however, Vander Bauwhede et al. (2003) find that Big 6 auditors do constrain income-decreasing earnings management more than non Big 6 auditors in Belgian private firms, while no audit quality difference is found in constraining income-increasing earnings management. In an attempt to unravel these mixed results, Vander Bauwhede and Willekens (2004) use alternative audit firm size measures, such as auditor market share, number of audit-firm clients, number of audit firm partners, total assets and operating profit of the audit firm, on a sample of consolidated financial statements and again do not find audit quality differentiation in the Belgian private client segment market. We extend this research by examining whether Big 4 auditors impose a constraint on earnings management in a large sample of private firms across different countries in Europe.

\subsection{Institutional influences on reporting incentives}

Besides ownership structure and other firm characteristics, also institutional factors determine financial reporting quality. A number of studies document that differences in institutional factors explain differences in timeliness, value relevance and earnings management (e.g. Ball et al, 2000; Ball et al. 2003; Fan and Wong, 2001; Pope and Walker, 1999; Leuz et al., 2003; Burgstahler et al. 2004; Bushman and Piotroski, 2005). Leuz et al. (2003) view investor protection as primary institutional determinant of financial reporting quality. Low earnings management, 
large equity markets, dispersed ownership patterns and highly developed corporate governance mechanisms are considered as complements and joint outcomes of strong investor protection. The incentives of (especially large) audit firms to supply a high quality audit are expected to depend upon the probability that an audit failure is detected and the risk of litigation. Audit firms are therefore expected to be more inclined to supply high quality audits in countries with strong investor protection.

On the other hand, in countries with strong investor protection, investor protection in itself might work as an effective deterrent against earnings management, leading to a smaller differential audit quality effect for firms domiciled in these countries compared to firms domiciled in countries with weak investor protection.

Empirical research documents that audit quality indeed differs across different legal environments (e.g. Francis and Wang, 2003; Maijoor and Vanstraelen, 2004). This raises the question to what extent audit quality differentiation (or lack thereof) is uniform for private firms across Europe. This study addresses this issue empirically.

\section{Hypotheses Development}

As argued above, important differences exist between public and private firms with regard to incentives of audit firms to supply high quality audits. While Big 4 auditors are generally considered to provide higher audit quality than non-Big 4 auditors in public firms, it is questioned whether this audit quality difference also holds in the private client segment of the European audit market.

In several European countries the private client audit market is less concentrated compared to for instance the US and the UK. In these less concentrated markets the traditional distinction between Big 4 and non-Big 4 audit firms might not be adequate. Therefore, we further subdivide the non-Big 4 audit firms in the socalled second-tier audit firms ${ }^{6}$ and small audit firms. In this respect, we expect a large auditor to provide a higher audit quality compared to a small auditor. Hence, Big 4 auditors are expected to provide a higher audit quality compared to non-Big 4 (both second-tier and small) auditors, while second-tier auditors are considered to provide a higher audit quality compared to small auditors. This leads us to the following hypothesis, stated in alternative form:

\footnotetext{
${ }^{6}$ Names of member firms were identified by visiting the websites of the Top 20 International Accounting Networks on the list of Accountancy (2002). Comparison of this list with the 1999 list revealed only one difference. In 2002 one firm had been replaced by number 23 of 1999.
} 
Hypothesis 1: European private firms engage significantly less in earnings management when audited by a large auditor compared to a small auditor.

Audit quality is considered to differ across different legal environments (e.g. Francis and Wang, 2003; Maijoor and Vanstraelen, 2004). Incentives for audit firms to supply high quality audits are expected to be higher in countries with strong investor protection. Audit quality differentiation in private firms is therefore expected to be stronger in countries with strong investor protection. This leads us to the following hypothesis, stated in alternative form:

Hypothesis 2: Large auditors provide a stronger constraint on earnings management in countries with strong investor protection compared to countries with weak investor protection.

\section{Research design}

\subsection{Sample}

We use the August 2003 version of the Amadeus database to collect our data ${ }^{7}$. Amadeus is a relatively new database which provides standardized financial statement data. We focus our analysis on a five-year period from 1998 to 2002. The initial sample consists of all privately held companies that have their domicile in one of the at that time- 15 member states of the European Union, that are required by law to have their financial statements audited and for which financial data and audit firm data are available in the Amadeus database. Observations of Austria, Germany, Greece, Italy and Sweden had to be excluded because of unavailability of audit firm data. In addition, Portugal is excluded due to insufficient observations regarding companies with Big 4 auditors. Finally, three countries were excluded because of missing accounting and institutional data. In particular, Ireland and Denmark are excluded because Amadeus does not provide data on depreciation and operating income for Irish companies and cash and short term debt for Danish companies, and Luxembourg is excluded because of missing institutional data. Hence, the remaining countries are Belgium, Finland, France, the Netherlands, Spain and the United Kingdom.

\footnotetext{
${ }^{7}$ Listing status and audit firm data is provided in Amadeus only for the final year. Therefore, previous versions of the Amadeus database were used to verify the listing status and audit firm data.
} 
Consistent with previous research, we exclude banks, insurance companies and other financial holdings (SIC codes between 6000 and 6799), public administrative institutions (SIC code 43 and SIC codes above 90000) as well as privately held subsidiaries of quoted companies as indicated in Amadeus ${ }^{8}$. Further, to eliminate extreme outliers, all accounting items needed to construct the earnings management measures are truncated at the $0.5^{\text {th }}$ and $99.5^{\text {th }}$ percentile .

For our industry-country analysis, the above selection criteria result in 64,831 firm-year observations, constituting 144 industry-country observations when analyzing the quality of Big 4 auditors compared to non-Big 4 auditors (6 countries $\mathrm{x}$ 12 industry group x 2 firm types) and 216 industry-country observations when further subdividing non-Big 4 audit firms in second-tier and small audit firms (6 countries $\mathrm{x}$ 12 industry group x 3 firm types). However, we further require a minimum of ten observations per unit of analysis, analogous to Burgstahler et al. (2004), resulting in 129 and 164 industry-country observations, respectively. This number is further reduced to 113 and 145 observations due to zero small losses in these eliminated subgroups, making the calculation of EM2 impossible.

Second-tier audit firms are identified as member firms of the Top 20 International Accounting Firms and Networks, excluding Big 4 audit firms (Accountancy, 2002).

\subsection{Earnings management proxies}

Discretionary accruals and earnings distributions have been heavily criticized as earnings management measures (e.g. Young, 1999; McNichols, 2000; Dechow et al. 2003; Beaver et al. 2003; Durtschi and Easton, 2004). In response to the criticisms, a growing number of studies are relying on an aggregate measure of earnings management behavior, as developed by Leuz et al. (2003) (e.g. Lang et al., 2003; Wysocki, 2004; Burgstahler et al., 2004). This measure is constituted of four different proxies capturing a wide range of earnings management activities: i.e. the magnitude of total accruals, the tendency of firms to avoid small losses, the smoothness of

\footnotetext{
${ }^{8}$ Financial institutions are excluded because of their specific accounting requirements, which differ substantially from those of industrial and commercial companies and which prevent them from freely selecting the accounting standards they apply. Public administrative institutions are excluded because of their specific nature. Management and financial reporting decisions of subsidiaries of quoted companies are likely to be influenced by public parent companies.

${ }_{9}$ While a more common method of excluding outliers involves excluding the upper and lower percentile of variable data, we prefer to use a less stringent method since wrongfully excluding too many outliers impedes generalizability.
} 
earnings relative to cash flows and the correlation of accounting accruals and operating cash flow.

The earnings management proxies that we use, are calculated at the industrycountry level for firms with a high quality auditor versus firms with a low quality auditor. This way, we further control for industry and country differences in firms' business processes and economic activities (Burgstahler et al., 2004). Similar to Burgstahler et al. (2004), we consider the following earnings management proxies:

\section{EM1: Magnitude of total accruals relative to operational cash flow}

The magnitude of total accruals can be used as an overall indication of using accounting discretion to manage earnings. Following Dechow et al. (1995), we compute accruals as ( $\triangle$ total current assets $-\triangle$ cash $)-(\triangle$ total current liabilities $-\triangle$ short term debt) - depreciation expense, where $\Delta$ denotes the change over the fiscal year. Hence, the extent in which discretion is exercised in reporting earnings by influencing accruals is measured by the magnitude of accruals relative to operating cash flow. The measure is computed as the median absolute value of total accruals scaled by the corresponding median absolute value of operational cash flow for each industry-country- audit quality subgroup. The scaling by operating cash flow controls for differences in firm size and performance (Burgstahler et al., 2004).

\section{EM2: Avoidance of Small Losses}

Burgstahler and Dichev (1997) and Degeorge et al. (1999) provide evidence that U.S. listed firms tend to avoid reporting losses and earnings declines. According to Dechow et al. (2000) managers avoid reporting losses or earnings declines in order to opportunistically delay reporting poor performance rather than signal that future performance will improve. As indicated above, also private firms have incentives to avoid reporting poor performance. To measure the extent in which firms avoid reporting small losses, we calculate the ratio of small profits to small losses at the industry-country level, for firms with a high quality auditor versus firms with a low quality auditor. A firm-year observation is classified as a small profit (small loss) if positive (negative) earnings fall within the range of one percent of lagged total assets. 


\section{EM3: Smoothing of operating income}

A negative correlation between accruals and operating cash flow indicates the use of accruals to smooth the variability in operating cash flows. While a negative correlation between accruals and operating cash flow is inherent to accrual accounting, differences in the magnitudes of this correlation indicate, ceteris paribus, variation in the extent of earnings smoothing ${ }^{10}$.

The degree with which the variability of reported earnings is reduced by using accruals can be measured with two different measures. The first one is defined by Leuz et al. (2003) as the standard deviation of operating income divided by the standard deviation of cash flow from operations, to control for differences in the variability of the firms' economic performance. The resulting ratio is multiplied by -1 so that higher values correspond to more earnings smoothing.

\section{EM4: Correlation between accruals and operating cash flow}

As a second measure of earnings smoothing, Leuz et al. (2003) use the contemporaneous Spearman correlation between the changes in total accruals and the changes in operational cash flow. The Spearman correlation coefficients are calculated for each industry-country- audit quality subgroup and multiplied by -1 , so that higher values again correspond to more earnings smoothing.

\section{$E M_{\text {Agg: }}$ : Aggregate earnings management measure}

By transforming the individual earnings management scores into percentage ranks and averaging these percentage ranks, the aggregate measure is expected to mitigate potential measurement error. Hence, we obtain $\mathrm{EM}_{\mathrm{Agg}}$ as follows:

$$
\begin{aligned}
\mathrm{EM}_{\mathrm{Agg}}= & \text { (percentage rank of EM1+ percentage rank of EM2 + percentage rank } \\
& \text { of EM3 + percentage rank of EM4)/4 }
\end{aligned}
$$

Similar, we obtain an earnings management index for two subcategories: (a) earnings discretion (EM $\mathrm{EM}_{\text {Discr }}$ ), the average of the percentage ranks of EM1 and EM2,

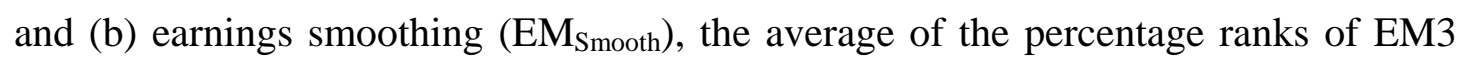
and EM4.

\footnotetext{
${ }^{10}$ Because accounting systems likely underreact to economic shocks, using accruals to signal firm performance results on average in a less negative (and in specific cases even positive) correlation with cash flows (Leuz et al., 2003).
} 


\subsection{Empirical model}

For the dependent variable we use the aggregate earnings management measure as well as the earnings management indices of the two subcategories, earnings discretion and earnings smoothing. There are three independent variables of interest in this study. First, we use a vector of audit dummies (AUD) indicating whether the company has a Big 4 auditor (B4) or not and whether the company has a second-tier auditor (ST) or not. In a first stage, the auditor of reference is the non-Big 4 auditor. The second-tier dummy is included only in a second stage when we further subdivide the non-Big 4 audit firms into second-tier and small audit firms. Here, the auditor of reference is the small auditor.

Second, we include two investor protection variables. In particular, we include a ranking index on legal protection (RLegal). This ranking index is computed as the ranking on the mean of three legal variables from La Porta et al. (1998), which measure the quality of the legal system or enforcement, i.e. efficiency of the judicial system, rule of law and corruption index. A high ranking indicates strong legal protection. In addition, we include a ranking index on the investor orientation of a country's financial system (ROrient), which is computed as the ranking on a measure from Peek et al. (2004). This measure is obtained using factor analysis on the common variation in 4 country-specific institutional variables. The first two variables are proxies for the governmental influence on business and accounting, and include the shareholder protection index of La Porta et al. (1998) and the source of a country's accounting principles, i.e. whether the country has a private standard setting body or not. The two other components of this measure are proxies for the objective of accounting regulation. They include the extent to which financial and tax accounting rules are aligned and the extent to which a country's accounting rules promote accrual accounting as measured by Hung (2001). A high ranking indicates a stronger investor orientation.

Third, to examine whether institutional factors have an influence on audit quality, we include interaction terms of the ranking indices with each of the audit dummies.

To control for differences in earnings management incentives and firm characteristics that are systematically associated with accruals, we include the following variables. First, we include the natural logarithm of total assets 
(LNASSETS) to proxy for the size of a company, which is expected to induce downward earnings management because of the potential government scrutiny which increases as firms are larger and more profitable (Watts and Zimmerman, 1990; Young, 1999).

Second, we include a leverage variable $(L E V)$, calculated as the ratio of total liabilities to total assets, which can have an impact on earnings management in two directions. While highly leveraged firms could be expected to engage more in upward earnings management to avoid debt covenant violations (Watts and Zimmerman, 1990; DeFond and Jiambalvo, 1994; Young, 1999), alternatively, high leverage may induce income-decreasing earnings management in financially distressed firms in view of contractual renegotiations (Becker et al.,1998).

Third, to control for differences in performance, we include the yearly percentage change in sales (GROWTH) and the yearly return on assets as measured by earnings divided by lagged total assets (ROA) (Young, 1999; Dechow et al., 1995). All control variables are computed as industry-level medians.

Finally, we include industry dummies (IND) to control for industry effects on earnings management. Similar to Burgstahler et al. (2004), the industry classification is based on Campbell (1996) and is illustrated in Table 1.

\section{- INSERT TABLE 1-}

Hence, our empirical model looks as follows:

$$
\begin{aligned}
& \text { EM }=\beta_{0}+\beta_{1} \text { AUD }+\beta_{2} \text { RLegal }+\beta_{3} \text { ROrient }+\beta_{4} \text { AUD } * \text { RLegal }+\beta_{5} \text { AUD * } \\
& \text { ROrient }+\beta_{6} \text { LNASSETS }+\beta_{7} \text { LEV }+\beta_{8} \text { GROWTH }+\beta_{9} \text { ROA }+\beta_{10} \text { IND }+\varepsilon
\end{aligned}
$$

where:

\section{Dependent variable}

EM = Earnings management measure indicating either the aggregate earnings management measure $\left(\mathrm{EM}_{\mathrm{Agg}}\right)$, earnings discretion $\left(\mathrm{EM}_{\text {Discr }}\right)$ or earnings smoothing $\left(\mathrm{EM}_{\mathrm{Smooth}}\right)$

\section{Independent variables}

AUD $\quad=$ Vector of audit dummies

(B4: Company has a Big 4 auditor $=1$, else $=0$; ST: Company has a second-tier auditor $=1$, else $=0$ ). The auditor of reference is the nonBig 4 auditor in Model 1 and the small auditor in Model 2 
RLegal = A ranking index on legal protection, computed as the ranking of the mean of three legal variables which measure the quality of the legal system or enforcement, i.e. efficiency of the judicial system, rule of law and corruption index (La Porta, 1998)

ROrient $\quad=$ A ranking index on the investor orientation of a country's financial system as measured by Peek et al. (2004). The score encompasses 4 country-specific institutional factors, i.e. La Porta et al.’s shareholder protection index, the source of a country's accounting principles, the extent to which financial and tax accounting rules are aligned and Hung ‘s (2001) accrual index

LNASSETS $_{\mathrm{t}}=$ Natural logarithm of total assets in year $\mathrm{t}$

$\mathrm{LEV}_{\mathrm{t}} \quad=$ Ratio of total liabilities to total assets in year $\mathrm{t}$

GROWTH $_{\mathrm{t}} \quad=$ Yearly percentage change in sales

$\mathrm{ROA}_{\mathrm{t}} \quad=$ Yearly return on assets as measured by earnings divided by lagged total assets

IND $\quad=$ Vector of industry dummies based on Campbell (1996), as illustrated in table 1. It is noted that Campbell 1 (Agriculture and Forestry) is the industry of reference

\subsection{Control for auditor choice}

There are several reasons why a private firm would choose a Big 4 auditor instead of a non-Big 4 auditor. First, private firms might prefer Big 4 audit firms if they desire a high audit quality and they believe that the reputation of Big 4 auditors reflects superior audit quality. There are a number reasons why a demand for audit quality would also exist in private firms. First, in the absence of market-based measures of firm-value, high quality reporting becomes particularly relevant for evaluation of managerial performance, resulting in a demand for high quality audits. In many private firms agency conflicts indeed continue to create the need for the monitoring of management since many private firms are not entirely run by ownermanagers (Ang, Cole and Lin, 2000). Moreover, bank financing results in agency conflicts between bankers and owners and bankers and management (VanderBauwhede and Willekens, 2002). Second, to the extent that financial reporting information is used in private companies to support personnel and compensation decisions, high quality auditing is called for (Chaney et al., 2004). Finally, having a 
Big 4 auditor could also in private firms be used to signal high financial reporting quality in order to obtain financing at the lowest possible cost (Beatty, 1989) or in view of the possibility of going public in the future or of being targeted for acquisition (Chaney et al., 2004). However, agency conflicts may be less in private firms because ownership and control are less separated, hereby reducing the demand for financial statements for monitoring managers (Fama and Jensen, 1983) and hence for a high quality audit.

Besides audit quality, private firms might also believe that Big 4 auditors can provide superior tax expertise, advisory services or other non-audit services (Chaney et al. 2004). However, according to Chaney et al. (2004), private firms do not view Big 4 auditors as superior in terms of the perceived quality of any provided services, since they do not find evidence that private firms in the UK, in contrast to public firms, pay a fee premium to Big 4 audit firms ${ }^{11}$. Since private firms face far less capital market pressure ${ }^{12}$ to hire a brand-name auditor, private firms would self-select the most cost-effective auditor types. Small, simple companies would be cheaper off choosing a non-Big 4 auditor while large, relatively complex companies appear to be cheaper off choosing a Big 4 auditor.

The results of Chaney et al. (2004) indicate that certain private firm-specific characteristics that influence financial reporting, and more specifically earnings management behavior, might also influence auditor choice. When certain variables that both affect earnings management and auditor choice have not been adequately controlled for in our regression analysis, auditor choice (Big 4/non-Big 4) would be endogenous in our analysis, hereby possibly confounding our results. Therefore we test whether Big 4 is endogenous in our earnings management (EM) model by performing the extended regression version of the Hausman specification test (Maddala, 2001, p. 498; Wooldridge, 2003, p.506).

\footnotetext{
${ }^{11}$ The results of Willekens and Achmadi (2003), indicate that private firms in Belgium do pay a price premium to large auditors. However, they do not control for self-selection. Using standard OLSregressions, Chaney et al. (2004) also find evidence of private firms paying a fee premium to Big 4 audit firms.

${ }^{12}$ Capital markets are considered to be broader than merely stock exchanges. Also private equity and creditor markets are considered. Capital market pressure is referred to as pressure coming from investors (i.e. shareholders and creditors) with regard to financial reporting quality. Investors require financial reporting quality to monitor and evaluate the firm's performance in order to supply capital at low cost.
} 
In particular, we estimate a self-selection model where auditor choice is explained by all the exogenous variables in the EM model. Since Big 4 is a dichotomous variable, a logistic regression is performed (results not reported). The effect of any omitted variables influencing auditor choice are now captured in the residual of the auditor choice-model. When we include this residual in the EM model and the coefficient on this residual is statistically significant, then the model is considered to suffer from an endogeneity bias caused by omitted variables influencing both earnings management and auditor choice. If this appears to be the case, we can control for the endogeneity of Big 4 by performing a Two-Stage-Least-Squares (2SLS) analysis, using the fitted probabilities of the auditor choice model as the instrumental variable (Maddala, 1983). In our case, however, the coefficient on the residual is not statistically significant $(\mathrm{p}=0,296)$, indicating that this model does not suffer from an endogeneity bias. Hence, Ordinary Least Squares (OLS) estimates are preferred to 2 SLS estimates.

\section{Results}

\subsection{Descriptive Statistics}

Table 2 illustrates our sample composition, mean percentage ranks of the four individual earnings management measures (EM1 to EM4) and mean values of the aggregate earnings management measure $\left(\mathrm{EM}_{\mathrm{Agg}}\right)$ for the different industry-country groups. Table 2 also includes values of our investor protection variables. Overall, industry groups with a Big 4 auditor have a lower aggregate earnings management measure compared to non-Big 4 auditors. This result is also observed at country level, except for the Netherlands and the UK. The same conclusion can generally be drawn when considering the individual earnings management measures. Subdividing nonBig 4 audit firms reveals a lower aggregate earnings management measure for secondtier audit firms compared to observations with a small auditor, while second-tier firm observations have a higher aggregate earnings management measure compared to Big 4 observations. For the individual earnings management measures, we observe a similar pattern for the earnings smoothing measures and one earnings discretion measure. 
Table 3 provides Spearman correlation coefficients of the different earnings management measures, audit quality, legal protection and investor orientation. All earnings management measures seem to be significantly correlated with each other. Audit quality is significantly negatively correlated with $\mathrm{EM}_{\mathrm{Agg}}$ and $\mathrm{EM}_{\text {Smooth }}$, but is not significantly correlated with $\mathrm{EM}_{\text {Discr }}$. While legal protection is strongly negatively correlated with all earnings management measures, investor orientation is not significantly correlated to any of the earnings management measures.

- INSERT TABLE 3 -

\subsection{Univariate Results}

Univariate results, as presented in Table 4, indicate that, overall, companies with a Big 4 auditor engage less in earnings management compared to companies with a non-Big 4 auditor. This audit quality difference is significant for the sample as a whole and for companies domiciled in countries with strong legal protection and weak investor orientation, but is not significant for companies domiciled in countries with weak legal protection and a strong investor orientation. Similarly, legal protection appears to provide a significant constraint on earnings management for companies with a Big 4 auditor, while this constraint is not significant for companies with a nonBig 4 auditor and for the total sample. Investor orientation on the other hand seems to provide a significant constraint on earnings management for companies with a nonBig 4 auditor, while this constraint is not significant for companies with a Big 4 auditor and for the total sample. Hence, while audit quality and legal protection appear to be complements, audit quality and investor orientation seem substitutes.

Univariate results on the two subcategories "earnings discretion" and “earnings smoothing” reveal only a significant audit quality difference for earnings discretion in countries with a weak investor orientation and for earnings smoothing, which is significant for the sample as a whole and for companies domiciled in countries with high legal protection and a weak investor orientation. As for the influence of institutional factors, we only find a significant constraint of investor orientation on earnings discretion for companies with a non-Big 4 auditor. 


\subsection{Multivariate Results}

\subsubsection{Aggregate earnings management measure}

Using the aggregate earnings management measure as defined by Leuz et al. (2003), it appears that both having a Big 4 auditor, compared to a non-Big 4 auditor, and being domiciled in a high investor protection country constrain earnings management, as indicated in Panel 1 of Table 5. However, the effect of having a Big 4 auditor in constraining earnings management appears to be moderated when the company is domiciled in a country with strong investor protection. Similar, the effect of a strong investor orientation and legal protection in constraining earnings management is moderated when the company has a Big 4 auditor. This suggests that audit quality and investor protection are substitutes in constraining earnings management in private firms, in the sense that the Big 4 audit quality effect attenuates when investor protection is stronger.

Subdividing the non-Big 4 audit firms in the so-called second-tier audit firms and small audit firms does not show significant differences in audit quality between these two types of audit firms. Panel 2 of Table 5 shows that only Big 4 audit firms provide a significantly larger constraint on earnings management in private firms compared to small audit firms. The coefficient for second-tier audit firms is negative but not significant. Moreover, when testing the equality of the coefficients on Big 4 and second-tier auditors, Big 4 auditors appear to provide a significantly larger constraint on earnings management compared to second-tier auditors. Again, the audit quality differentiation is moderated in countries with a strong investor orientation and legal protection.

\section{- INSERT TABLE 5 -}

\subsubsection{Earnings discretion}

In addition, we analyze the rankings of the two subcategories "earnings discretion” and “earnings smoothing”. Table 6 presents the regression results using earnings discretion (EM $\mathrm{EMiscr}_{\text {}}$ ) as our dependent variable. Overall, Big 4 auditors do not seem to impose a stronger constraint on earnings discretion compared to non-Big 4 auditors, while companies in countries with a strong legal protection engage significantly less in earnings management. It appears however, that B4 auditors and both legal protection and investor orientation provide a constraint on earnings 
discretion but the effect of a strong investor protection in constraining earnings discretion is moderated when having a Big 4 auditor and vice versa.

Subdivision of the non-Big 4 audit firms does not provide evidence of significant different levels of earnings discretion between second-tier audit firms and small audit firms, as presented in Panel 2 of Table 6.

\section{- INSERT TABLE 6 -}

\subsubsection{Earnings smoothing}

As presented in Table 7, both Big 4 audit firms and investor protection appear to constrain earnings smoothing. However, when analyzing the effect of institutional factors on the audit quality effect, the constraining effect of investor orientation on earnings smoothing is moderated when having a Big 4 auditor. Finally, there appears to be no significant difference in the level of earnings smoothing between second-tier audit firms and small audit firms.

\section{- INSERT TABLE 7 -}

\subsection{Sensitivity Analysis}

Cross-country differences in a private firm's reporting behavior and in audit quality differentiation are expected to be influenced by differences in financial reporting and tax accounting alignment. One of our investor protection variables, i.e. investor orientation (ROrient), includes the extent to which financial and tax accounting rules are aligned. However, to examine to what extent this tax alignment is driving cross-country differences in auditor differentiation, an additional analysis is performed, replacing ROrient by a dummy variable TAX. The TAX variable takes on a value of one when financial reporting and tax rules are highly aligned (Belgium, Finland, France) and zero otherwise (Spain, the Netherlands and the UK).

The results (not reported) of this analysis indicate that, when using the aggregate earnings management measure and earnings discretion as dependent variable, audit quality differentiation is enhanced in countries with a high tax alignment. Private companies with a Big 4 (non-Big 4) auditor engage significantly less (more) in earnings management in countries with a high tax-alignment compared to countries with a low tax alignment. Using earnings smoothing as dependent 
variable, however, does not provide evidence of differences in audit quality differentiation between countries with high and low tax alignment. In each of the cases, explanatory power of the regression models including the TAX variable is lower compared to the models including investor orientation, which confirms are decision to use the latter variable in our analysis.

\section{Conclusion}

Previous studies have documented that Big 4 audit firms impose a constraint on earnings management in public firms. This study examines (1) whether audit quality differences, in terms of larger audit firms providing a larger constraint on earnings management, also hold in private firms and (2) to what extent this audit quality differentiation is uniform across Europe.

Using data on private firms of six European countries, this study provides evidence that privately held companies engage less in earnings management when they have a Big 4 auditor compared to a non-Big 4 auditor. Consistent with Burgstahler et al. (2004), we find that private companies domiciled in countries with a stronger investor protection engage less in earnings management. However, our results further suggest that audit quality and a strong investor protection are substitutes in constraining earnings management in private firms, in the sense that the quality difference between Big 4 and non-Big 4 audit firms attenuates in countries with stronger investor protection.

Although audit markets are in general less concentrated in Europe, subdividing non-Big 4 audit firms in second-tier and small audit firms does not provide support for an audit quality difference between second-tier audit firms and small audit firms with regard to earnings management.

These findings suggest that audit quality differentiation also holds in private firms, indicating that reputation concerns of Big 4 auditors are sufficiently strong to control the higher moral hazard risk in the private client segment market. Moreover, we find the quality difference between Big 4 and non-Big 4 audit firms attenuates in countries with stronger investor protection. Our findings contribute to the recent literature on demand and supply of financial reporting quality in private firms, constituting the majority of the EU economy and the EU audit services market. 


\section{References}

Ang J., R. Cole and J. Lin (2000), Agency Costs and Ownership Structure, Journal of Finance, Vol. 55, pp. 81-106.

Ball, R. S.P. Kothari and A. Robin (2000), The Effect of International Institutional Factors on Properties of Accounting Earnings, Journal of Accounting and Economics, Vol. 29, No. 1, pp. 1-51.

Ball, R., A. Robin and J.S. Wu (2003), Incentives versus Standards: Properties of Accounting Income in Four East Asian Countries, and Implications for Acceptance of IAS, Journal of Accounting and Economics, Vol.36, No. 1-3, pp. 235-270.

Ball, R. and L. Shivakumar (2005), Earnings Quality in U.K. Private Firms, Journal of Accounting and Economics, Vol.39, No.1, pp.83-128.

Becker, CL, M.L. DeFond, J. Jiambalvo and K.R. Subramanyam (1998), The Effect of Audit Quality on Earnings Management, Contemporary Accounting Research, Vol. 15, No. 1, pp. 1-24.

Beatty, R. (1989), Auditor Reputation and the Pricing of Initial Public Offerings, The Accounting Review, Vol. 64, No. 4, pp. 693-709.

Beatty, A. and D.G. Harris (1998), The effects of Taxes, Agency Costs and Information Asymmetry on Earnings Management: A comparison of public and private Firms, Review of Accounting Studies, Vol. 3, pp. 299-326.

Beatty, A.L., B. Ke and K.R. Petroni (2002), Earnings Management to Avoid Earnings Declines across Publicly and Privately Held Banks, The Accounting Review, Vol. 77, No. 3, pp. 547-570.

Beaver, W.H., M.F. McNichols, K.K. Nelson (2003), An alternative interpretation of the discontinuity in earnings distributions, Working Paper, Graduate School of Business, Stanford University.

Burgstahler D.C. and I. Dichev (1997), Earnings Management to Avoid Earnings Decreases and losses, Journal of Accounting and Economics, Vol. 24, pp. 99-126.

Burgstahler, D.C., L. Hail and C. Leuz (2004) The Importance of Reporting Incentives: Earnings Management in European Private and Public Firms, Working Paper, http://ssrn.com/abstract=484682 .

Bushman, R. and J. Piotroski (2005), Financial reporting incentives for conservative accounting: the influence of legal and political institutions, Journal of Accounting and Economics, forthcoming. 
Coppens, L. and E. Peek (2005), An Analysis of Earnings Management by European Private Firms, Journal of International Accounting, Auditing and Taxation, forthcoming.

Campbell, J.Y. (1996), Understanding Risk and Return, Journal of political Economy, Vol. 104, pp. 298-345.

Chaney, P.K., D.C. Jeter, and L. Shivakumar (2004), Self-Selection of Auditors and Audit Pricing in Private Firms, The Accounting Review, Vol. 79, No. 1, pp. 51-73.

DeAngelo, L. (1981), Auditor Size and Audit Quality, Journal of Accounting and Economics, Vol. 3, pp. 183-199.

Dechow, P.M., S.A. Richardson and A.I. Tuna (2000), Are benchmark beaters doing anything wrong?, Working paper, University of Michigan.

Dechow, P.M., S.A. Richardson and I. Tuna (2003), Why are earnings kinky? An examination of the earnings management explanation, Review of Accounting Studies, Vol. 8, pp. 335-384.

Dechow, P.M., R.G. Sloan and A.P. Sweeney (1995), Detecting Earnings Management, The Accounting Review, Vol. 70, No. 2, pp. 193-225.

Defond, M.L. and J. Jiambalvo (1991), Incidence and Circumstances of Accounting Errors, Accounting Review, Vol. 66, pp. 643-655.

Defond, M.L. and J. Jiambalvo (1993), Factors Related to Auditor-Client Disagreements over Income-Increasing Accounting Methods, Contemporary Accounting Research, Vol. 9, pp. 415-431.

Defond, M.L. and J. Jiambalvo (1994), Debt Covenant Violation and Manipulation of Accruals, Journal of Accounting and Economics, Vol. 17, No. 1-2, pp. 145-176.

Degeorge, F., J. Patel and R. Zeckhauser (1999), Earnings Management to Exceed Thresholds, The Journal of Business, Vol. 72, pp. 1-33.

Durtschi, C. and P. Easton (2004), Earnings Management? Alternative explanations for observed discontinuities in the frequency distribution of earnings, earnings changes and analyst forecast errors, Working Paper, University of Notre Dame.

Fan, J. and T. Wong (2001), Corporate ownership structure and the informativeness of accounting earnings in East Asia, Journal of Accounting and Economics, Vol. 33, pp. 401-426

Francis, J. and D. Wang (2004), Investor Protection, Auditor Conservatism and Earnings Quality: Are Big 4 Audit Firms Conservative Only in the United States?, Working Paper, University of Missouri-Columbia. 
Francis, J.R., E.L. Maydew and H.C. Sparks (1999), The role of Big Six Auditors in the credible reporting of Accruals, Auditing: A Journal of practice \& Theory, Vol. 18, pp. 17-34.

Gore, P, P.F. Pope and A.K. Singh (2001), Non-Audit Services, Auditor Independence and Earnings Management, Working Paper, Lancaster University.

Healy, P.M. and J. M. Wahlen (1999) A Review of the Earnings Management Literature and its Implications for Standard Setting, American Accounting Association, Accounting Horizons, Vol. 13, No. 4, pp. 365-383.

Hung, M. (2001), Accounting Standards and Value Relevance of Financial Satements: An International Analysis, Journal of Accounting and Economics, Vol. 36, pp. 401-420.

La Porta, R., F. Lopez-de-Silanes and A. Shleifer (1998), Law and Finance, Journal of Political Economy, Vol. 106. No. 6, pp. 1113-1155.

Lang, M. J. Ready and M. Yetman (2003), How Representative Are Firms that Are Cross-Listed in the United States? An Analysis of Accounting Quality, Journal of Accounting Research, Vol. 41, No. 2, pp. 363-386.

Leuz, C., D. Nanda and P.D. Wysocki (2003), Earnings Management and Investor Protection: An International Comparison, Journal of Financial Economics, Vol. 69, No. 3, pp. 505-528.

Maddala, G.S. (2001), Introduction to Econometrics, New York, John Wiley.

Maijoor, S. and A. Vanstraelen (2002), Earnings management: The Effects of National Audit Environment, Audit Quality and International Capital Markets, Working Paper, Maastricht University.

McNichols, M. (2000), Research Design Issues in Earnings Management Studies, Journal of Accounting and Public Policy, Vol. 19, No. 4-5, pp. 313-345.

Peek, E., W.F.J. Buijink, and L.Coppens (2004), "Accounting Conservatism in the European Union: The Influence of Institutions and Incentives", Working Paper, http://ssrn.com/abstract=511822 .

Pope, P. and M. Walker (1999), International Differences in the Timeliness, Conservatism and Classification of Earnings, Journal of Accounting Research, Vol. 37, Supplement, pp. 53-99.

Sercu, P., H. Vander Bauwhede and M. Willekens (2002), Earnings Quality in privately held firms: the roles of external audits, stakeholders, and governance mechanisms, Research Report No. 0235, Catholic University Leuven. 
Subramanyam, K.R. (1996), The Pricing of Discretionary Accruals, Journal of Accounting and Economics, Vol. 22, No. 1-3, pp. 249-281.

Vander Bauwhede H. and M. Willekens (2002), Evidence on (the lack of) auditquality differentiation in the private client segment of the Belgian audit market, Research Report No. 0240, Catholic University Leuven.

Vander Bauwhede, H. and M. Willekens (2004), Evidence on (the lack of) Auditquality Differentiation in the Private Client Segment of the Belgian Audit Market, European Accounting Review, Vol. 13, No. 3, pp. 501-522.

Vander Bauwhede, H., M. Willekens and A. Gaeremynck (2003)Audit quality, public ownership and firms' discretionary accruals management, International Journal of Accounting, Vol. 38, No. 1, pp. 1-22.

Watts, R.L. and J.L. Zimmerman (1990), Positive Accounting Theory: A Ten Year Perspective, The Accounting Review, Vol. 65. No. 1, pp. 131-156.

Willekens, M. and C. Achmadi (2003), Pricing and Supplier Concentration in the Private Client Segment of the Audit Market: Market Power or Competition?, The International Journal of Accounting, Vol. 38, No. 4, pp. 431-455.

Wooldridge, J. (2003), Introductory Econometrics: A modern Approach, $2^{\text {nd }}$ edn, Cincinatti, OH: South Western College Publishing.

Wysocki, P. (2004), Discussion of Ultimate Ownership, Income Management and legal and Extra-Legal Institutions, Journal of Accounting Research, vol. 42, No. 2, pp. 465-474.

Young, S. (1999), Systematic Measurement Error in the Estimation of Discretionary Accruals: an Evaluation of Alternative Modeling Procedures, Journal of Business Finance and Accounting, Vol. 26, pp. 833-862. 
Table 1

\section{Industry Classification}

\begin{tabular}{lll}
\hline No & Industry group & Sic-code \\
1 & Agriculture and Forestry & $2,7-9$ \\
2 & Petroleum industry & 13,29 \\
3 & Consumer durables & $25,30,36-37,39,50,55,57$ \\
4 & Basic industry & $10,12,14,24,26,28$, , 33 \\
5 & Food/tobacco & $1,20,21,54$ \\
6 & Construction & $15-17,32,52$ \\
7 & Capital goods & $34-35,38$ \\
8 & Transportation & $40-42,44,45,47$ \\
9 & Utilities & $46,48,49$ \\
10 & Textiles/ trade & $22-23,31,51,53,56,59$ \\
11 & Service & $72-73,75,76,80,81,82,83,84,86-88,89$ \\
12 & Leisure & $27,58,70,78-79$ \\
& & \\
\hline
\end{tabular}




\section{Table 2}

Sample Composition and Descriptive Statistics

\begin{tabular}{|c|c|c|c|c|c|c|c|c|c|c|c|c|c|c|}
\hline \multirow[b]{2}{*}{ Country } & \multirow[b]{2}{*}{ Auditor } & \multicolumn{2}{|c|}{ B4 vs. Non-B4 } & \multicolumn{2}{|c|}{ B4 vs. ST vs. Small } & \multicolumn{2}{|c|}{ Earnings Discretion } & \multicolumn{2}{|c|}{ Earnings Smoothing } & \multirow[b]{2}{*}{$\begin{array}{l}\text { EMAgg } \\
\text { (Mean) }\end{array}$} & \multicolumn{2}{|l|}{ Quality } & \multicolumn{2}{|l|}{ Investor } \\
\hline & & $\begin{array}{l}\text { Industry } \\
\text { Obs . } \\
\end{array}$ & $\begin{array}{l}\text { Firm- } \\
\text { years }\end{array}$ & $\begin{array}{l}\text { Industry } \\
\text { Obs. }\end{array}$ & $\begin{array}{l}\text { Firm- } \\
\text { years }\end{array}$ & $\begin{array}{l}\text { EM1 } \\
\text { (Mean) }\end{array}$ & $\begin{array}{l}\text { EM2 } \\
\text { (Mean) }\end{array}$ & $\begin{array}{l}\text { EM3 } \\
\text { (Mean) }\end{array}$ & $\begin{array}{l}\text { EM4 } \\
\text { (Mean) }\end{array}$ & & $\begin{array}{l}\text { Legal } \\
\text { System }^{\text {a }}\end{array}$ & RLegal & Orientation $^{b}$ & ROrient \\
\hline Belgium & $\begin{array}{l}\text { B4 } \\
\text { Non-B4 } \\
\text { ST } \\
\text { Small }\end{array}$ & $\begin{array}{l}10 \\
11\end{array}$ & $\begin{array}{l}3478 \\
5762\end{array}$ & $\begin{array}{l}10 \\
9 \\
11\end{array}$ & $\begin{array}{l}3478 \\
884 \\
4867\end{array}$ & $\begin{array}{l}0.712 \\
0.689 \\
0.695 \\
0.693\end{array}$ & $\begin{array}{l}2.165 \\
3.295 \\
5.233 \\
3.353\end{array}$ & $\begin{array}{l}-0.618 \\
-0.584 \\
-0.564 \\
-0.586\end{array}$ & $\begin{array}{l}0.896 \\
0.928 \\
0.921 \\
0.925\end{array}$ & $\begin{array}{l}54.082 \\
68.152 \\
64.741 \\
65.243\end{array}$ & 9.44 & 4 & -0.830 & 1 \\
\hline Finland & $\begin{array}{l}\text { B4 } \\
\text { Non-B4 } \\
\text { ST } \\
\text { Small } \\
\end{array}$ & $\begin{array}{l}10 \\
5\end{array}$ & $\begin{array}{l}1427 \\
155\end{array}$ & $\begin{array}{l}10 \\
3 \\
2 \\
\end{array}$ & $\begin{array}{l}1427 \\
79 \\
48 \\
\end{array}$ & $\begin{array}{l}0.513 \\
0.685 \\
0.624 \\
0.591 \\
\end{array}$ & $\begin{array}{l}4.926 \\
2.017 \\
2.000 \\
2.000 \\
\end{array}$ & $\begin{array}{l}-0.761 \\
-0.628 \\
-0.651 \\
-0.862 \\
\end{array}$ & $\begin{array}{l}0.798 \\
0.840 \\
0.846 \\
0.805 \\
\end{array}$ & $\begin{array}{l}28.839 \\
40.487 \\
40.920 \\
23.535 \\
\end{array}$ & 10.00 & 5.5 & -0.494 & 2 \\
\hline France & $\begin{array}{l}\text { B4 } \\
\text { Non-B4 } \\
\text { ST } \\
\text { Small }\end{array}$ & $\begin{array}{l}11 \\
10\end{array}$ & $\begin{array}{l}2653 \\
15829\end{array}$ & $\begin{array}{l}11 \\
4 \\
10\end{array}$ & $\begin{array}{l}2653 \\
103 \\
15552\end{array}$ & $\begin{array}{l}0.683 \\
0.626 \\
0.614 \\
0.626\end{array}$ & $\begin{array}{l}2.184 \\
3.941 \\
1.625 \\
3.925\end{array}$ & $\begin{array}{l}-0.637 \\
-0.616 \\
-0.662 \\
-0.616 \\
\end{array}$ & $\begin{array}{l}0.878 \\
0.910 \\
0.900 \\
0.909\end{array}$ & $\begin{array}{l}48.029 \\
61.814 \\
42.866 \\
59.862 \\
\end{array}$ & 8.68 & 2 & -0.290 & 3 \\
\hline Netherlands & $\begin{array}{l}\text { B4 } \\
\text { Non-B4 } \\
\text { ST } \\
\text { Small } \\
\end{array}$ & $\begin{array}{l}9 \\
4\end{array}$ & $\begin{array}{l}868 \\
154\end{array}$ & $\begin{array}{l}1 \\
4 \\
\end{array}$ & $\begin{array}{l}868 \\
10 \\
122 \\
\end{array}$ & $\begin{array}{l}0.661 \\
0.598 \\
0.860 \\
0.569 \\
\end{array}$ & $\begin{array}{l}2.299 \\
0.875 \\
2.000 \\
0.625 \\
\end{array}$ & $\begin{array}{l}-0.631 \\
-0.522 \\
-1.111 \\
-0.483 \\
\end{array}$ & $\begin{array}{l}0.865 \\
0.853 \\
0.745 \\
0.865 \\
\end{array}$ & $\begin{array}{l}46.079 \\
40.044 \\
33.535 \\
40.647 \\
\end{array}$ & 10.00 & 5.5 & 0.951 & 5 \\
\hline Spain & $\begin{array}{l}\text { B4 } \\
\text { Non-B4 } \\
\text { ST } \\
\text { Small }\end{array}$ & $\begin{array}{l}11 \\
10\end{array}$ & $\begin{array}{l}5701 \\
14886\end{array}$ & $\begin{array}{l}11 \\
9 \\
10\end{array}$ & $\begin{array}{l}5701 \\
993 \\
13811 \\
\end{array}$ & $\begin{array}{l}0.630 \\
0.587 \\
0.629 \\
0.579 \\
\end{array}$ & $\begin{array}{l}3.779 \\
6.642 \\
5.656 \\
6.852 \\
\end{array}$ & $\begin{array}{l}-0.684 \\
-0.604 \\
-0.568 \\
-0.602 \\
\end{array}$ & $\begin{array}{l}0.878 \\
0.898 \\
0.895 \\
0.899 \\
\end{array}$ & $\begin{array}{l}51.659 \\
62.544 \\
62.807 \\
60.716 \\
\end{array}$ & 7.14 & 1 & 0.881 & 4 \\
\hline $\begin{array}{l}\text { United } \\
\text { Kingdom }\end{array}$ & $\begin{array}{l}\text { B4 } \\
\text { Non-B4 } \\
\text { ST } \\
\text { Small } \\
\end{array}$ & $\begin{array}{l}12 \\
10\end{array}$ & $\begin{array}{l}6126 \\
7314\end{array}$ & $\begin{array}{l}12 \\
9 \\
10 \\
\end{array}$ & $\begin{array}{l}6126 \\
2564 \\
4725 \\
\end{array}$ & $\begin{array}{l}0.684 \\
0.631 \\
0.648 \\
0.643 \\
\end{array}$ & $\begin{array}{l}2.292 \\
1.961 \\
1.754 \\
2.189 \\
\end{array}$ & $\begin{array}{l}-0.614 \\
-0.684 \\
-0.702 \\
-0.648 \\
\end{array}$ & $\begin{array}{l}0.876 \\
0.866 \\
0.864 \\
0.863 \\
\end{array}$ & $\begin{array}{l}50.950 \\
39.226 \\
37.768 \\
44.241 \\
\end{array}$ & 9.22 & 3 & 1.788 & 6 \\
\hline Total & $\begin{array}{l}\text { B4 } \\
\text { Non-B4 } \\
\text { ST } \\
\text { Small } \\
\end{array}$ & $\begin{array}{l}63 \\
50\end{array}$ & $\begin{array}{l}20253 \\
44100\end{array}$ & $\begin{array}{l}63 \\
35 \\
47 \\
\end{array}$ & $\begin{array}{l}20253 \\
4633 \\
39125 \\
\end{array}$ & $\begin{array}{l}0.649 \\
0.637 \\
0.655 \\
0.629 \\
\end{array}$ & $\begin{array}{l}2.932 \\
3.506 \\
3.665 \\
3.682 \\
\end{array}$ & $\begin{array}{l}-0.657 \\
-0.614 \\
-0.634 \\
-0.612 \\
\end{array}$ & $\begin{array}{l}0.866 \\
0.891 \\
0.886 \\
0.893 \\
\end{array}$ & $\begin{array}{l}46.855 \\
54.962 \\
51.874 \\
54.798 \\
\end{array}$ & & & & \\
\hline
\end{tabular}

a The mean of three variables which measure the quality of the legal system or enforcement, i.e. efficiency of the judicial system, rule of law and corruption index (La Porta, 1998). b Encompasses 4 country specific institutional factors, i.e. La Porta et al. 's shareholder protection index, the source of a country's accounting principles, the extent to which financial and tax accounting rules are aligned and Hung 's (2001) accrual index (Peek et al., 2004). 
Table 3

Earnings Management Measures:

Spearman Correlation Coefficients

\begin{tabular}{lllllll}
\hline \multicolumn{1}{c}{ Variable } & $\mathrm{EM}_{\text {Discr }}$ & $\mathrm{EM}_{\text {Smooth }}$ & $\mathrm{EM}_{\mathrm{Agg}}$ & $\mathrm{B} 4$ & RLegal & ROrient \\
$\mathrm{EM}_{\text {Discr }}$ & 1 & & & & & \\
$\mathrm{EM}_{\text {Smooth }}$ & $0.338^{* *}$ & 1 & & & & \\
$\mathrm{EM}_{\text {Agg }}$ & $0.743^{* *}$ & $0.873^{* *}$ & 1 & & & \\
$\mathrm{~B} 4$ & -0.069 & $-0.268^{* *}$ & $-0.216^{*}$ & 1 & & \\
RLegal & $-0.292^{* *}$ & $-0.187^{*}$ & $-0.278^{* *}$ & 0.092 & 1 & \\
ROrient & -0.137 & -0.112 & -0.151 & 0.029 & $-0.205^{*}$ & 1 \\
\hline
\end{tabular}

*, **, significantly different from zero at the $\alpha=0.05$ and 0.01 level respectively (two-tailed)

$\begin{array}{ll}\mathrm{EM}_{\mathrm{Agg}} & =\text { Aggregate earnings management measure } \\ \mathrm{EM}_{\text {Discr }} & =\text { Earnings discretion measure } \\ \mathrm{EM}_{\text {Smooth }} & =\text { Earnings smoothing measure } \\ \text { RLegal } & =\text { A ranking index on legal protection, computed as the ranking of the mean of three legal } \\ & \text { variables which measure the quality of the legal system or enforcement, i.e. efficiency of } \\ & \text { the judicial system, rule of law and corruption index (La Porta, 1998). } \\ & =\text { A ranking index on the investor orientation of a country's financial system as measured } \\ & \text { by Peek et al. (2004). The score encompasses } 4 \text { country-specific institutional factors, i.e. } \\ & \text { La Porta et al. 's shareholder protection index, the source of a country's accounting } \\ & \text { principles, the extent to which financial and tax accounting rules are aligned and Hung 's } \\ & \text { (2001) accrual index } \\ & =\text { Company has a Big } 4 \text { auditor = 1; else } 0\end{array}$


Table 4

Univariate Analysis

\begin{tabular}{|c|c|c|c|c|c|}
\hline $\mathbf{E M}_{\text {Agg }}$ & $\begin{array}{c}\text { Big } 4 \\
\text { Mean } \\
(\mathrm{N}) \\
\end{array}$ & $\begin{array}{c}\text { Non-Big } 4 \\
\text { Mean } \\
(\mathrm{N}) \\
\end{array}$ & $\begin{array}{c}\text { Total Sample } \\
\text { Mean } \\
(\mathrm{N}) \\
\end{array}$ & $\begin{array}{l}\text { Difference } \\
\text { t-statistic }\end{array}$ & $\begin{array}{c}\text { Difference } \\
\text { Z-statistic Wilcoxon } \\
\text { Mann Whitney }\end{array}$ \\
\hline Total Sample & $\begin{array}{c}46.855 \\
(63)\end{array}$ & $\begin{array}{c}54.962 \\
(50)\end{array}$ & & $-2.433 * *$ & $-2.286^{* *}$ \\
\hline Strong Legal Protection & $\begin{array}{c}42.894 \\
(29)\end{array}$ & $\begin{array}{l}55.614 \\
(20)\end{array}$ & $\begin{array}{c}48.086 \\
(49)\end{array}$ & $-2.438 * *$ & $-2.299 * *$ \\
\hline Weak Legal Protection & $\begin{array}{c}50.234 \\
(34)\end{array}$ & $\begin{array}{l}54.528 \\
(30)\end{array}$ & $\begin{array}{c}52.247 \\
(64)\end{array}$ & -0.976 & -1.016 \\
\hline $\begin{array}{c}\text { Difference } \\
\text { t-statistic }\end{array}$ & $-1.927^{*}$ & 0.186 & -1.222 & & \\
\hline $\begin{array}{c}\text { Difference } \\
\text { Z-statistic Wilcoxon Mann Whitney }\end{array}$ & $-1.779 *$ & -0.040 & -1.182 & & \\
\hline Strong Investor Orientation & $\begin{array}{l}49.824 \\
(32)\end{array}$ & $\begin{array}{l}49.078 \\
(24)\end{array}$ & $\begin{array}{l}49.504 \\
(56)\end{array}$ & 0.153 & -0.414 \\
\hline Weak Investor Orientation & $\begin{array}{l}43.791 \\
(31)\end{array}$ & $\begin{array}{l}60.394 \\
(26)\end{array}$ & $\begin{array}{c}51.364 \\
(57)\end{array}$ & $-3.827 * * *$ & $-3.509 * * *$ \\
\hline $\begin{array}{c}\text { Difference } \\
\text { t-statistic }\end{array}$ & 1.573 & $-2.060 * *$ & -0.548 & & \\
\hline $\begin{array}{c}\text { Difference } \\
\text { Z-statistic Wilcoxon Mann Whitney }\end{array}$ & -1.512 & $-2.000 * *$ & -0.640 & & \\
\hline $\mathbf{E M}_{\text {Discr }}$ & $\begin{array}{c}\text { Big } 4 \\
\text { Mean } \\
(\mathrm{N})\end{array}$ & $\begin{array}{l}\text { Non-Big } 4 \\
\text { Mean } \\
(\mathrm{N})\end{array}$ & $\begin{array}{c}\text { Total Sample } \\
\text { Mean } \\
(\mathrm{N})\end{array}$ & $\begin{array}{c}\text { Difference } \\
\text { t-statistic }\end{array}$ & $\begin{array}{c}\text { Difference } \\
\text { Z-statistic Wilcoxon } \\
\text { Mann Whitney }\end{array}$ \\
\hline Total Sample & $\begin{array}{c}49.227 \\
(63)\end{array}$ & $\begin{array}{c}51.974 \\
(50)\end{array}$ & & -0.763 & -0.734 \\
\hline Strong Legal Protection & $\begin{array}{c}46.376 \\
(29)\end{array}$ & $\begin{array}{l}48.153 \\
(20)\end{array}$ & $\begin{array}{c}47.101 \\
(49)\end{array}$ & -0.292 & -0.203 \\
\hline Weak Legal Protection & $\begin{array}{c}51.659 \\
(34)\end{array}$ & $\begin{array}{c}54.521 \\
(30)\end{array}$ & $\begin{array}{c}53.001 \\
(64)\end{array}$ & -0.659 & -0.478 \\
\hline $\begin{array}{c}\text { Difference } \\
\text { t-statistic }\end{array}$ & -1.163 & -1.025 & -1.651 & & \\
\hline $\begin{array}{c}\text { Difference } \\
\text { Z-statistic Wilcoxon Mann Whitney }\end{array}$ & -1.130 & -1.089 & $-1.706^{*}$ & & \\
\hline Strong Investor Orientation & $\begin{array}{c}50.920 \\
(32)\end{array}$ & $\begin{array}{c}46.064 \\
(24)\end{array}$ & $\begin{array}{c}48.839 \\
(56)\end{array}$ & 0.866 & -0.969 \\
\hline Weak Investor Orientation & $\begin{array}{l}47.481 \\
(31)\end{array}$ & $\begin{array}{l}57.429 \\
(26)\end{array}$ & $\begin{array}{l}52.018 \\
(57)\end{array}$ & $-2.262 * *$ & $-2.099 * *$ \\
\hline $\begin{array}{c}\text { Difference } \\
\text { t-statistic }\end{array}$ & 0.759 & $-2.054 * *$ & -0.890 & & \\
\hline $\begin{array}{c}\text { Difference } \\
\text { Z-statistic Wilcoxon Mann Whitney }\end{array}$ & -0.873 & $-1.923 *$ & -0.781 & & \\
\hline
\end{tabular}

(Continued on next page) 
Table 4

Univariate Analysis (Continued)

\begin{tabular}{|c|c|c|c|c|c|}
\hline $\mathbf{E M}_{\text {Smooth }}$ & $\begin{array}{c}\text { Big } 4 \\
\text { Mean } \\
(\mathrm{N})\end{array}$ & $\begin{array}{l}\text { Non-Big } 4 \\
\text { Mean } \\
(\mathrm{N})\end{array}$ & $\begin{array}{c}\text { Total Sample } \\
\text { Mean } \\
\text { (N) }\end{array}$ & $\begin{array}{c}\text { Difference } \\
\text { t-statistic }\end{array}$ & $\begin{array}{c}\text { Difference } \\
\text { Z-statistic Wilcoxon } \\
\text { Mann Whitney }\end{array}$ \\
\hline Total Sample & $\begin{array}{c}44.483 \\
(63)\end{array}$ & $\begin{array}{c}57.951 \\
(50)\end{array}$ & & $-2.903 * * *$ & $-2.830 * * *$ \\
\hline Strong Legal Protection & $\begin{array}{l}39.411 \\
(29)\end{array}$ & $\begin{array}{c}63.075 \\
(20)\end{array}$ & $\begin{array}{c}49.070 \\
(49)\end{array}$ & $-3.278 * * *$ & $-3.133 * * *$ \\
\hline Weak Legal Protection & $\begin{array}{c}48.809 \\
(34)\end{array}$ & $\begin{array}{l}54.535 \\
(30)\end{array}$ & $\begin{array}{l}51.493 \\
(64)\end{array}$ & -0.957 & -0.895 \\
\hline $\begin{array}{c}\text { Difference } \\
\text { t-statistic }\end{array}$ & -1.540 & 1.208 & -0.503 & & \\
\hline $\begin{array}{c}\text { Difference } \\
\text { Z-statistic Wilcoxon Mann Whitney }\end{array}$ & -1.476 & -1.129 & -0.382 & & \\
\hline Strong Investor Orientation & $\begin{array}{c}48.728 \\
(32)\end{array}$ & $\begin{array}{l}52.0926 \\
\text { (24) }\end{array}$ & $\begin{array}{l}50.170 \\
(56)\end{array}$ & -0.476 & -0.315 \\
\hline Weak Investor Orientation & $\begin{array}{l}40.101 \\
(31)\end{array}$ & $\begin{array}{l}63.359 \\
(26)\end{array}$ & $\begin{array}{l}50.710 \\
(57)\end{array}$ & $-3.956 * * *$ & $-3.645 * * *$ \\
\hline $\begin{array}{c}\text { Difference } \\
\text { t-statistic }\end{array}$ & 1.414 & -1.645 & -0.113 & & \\
\hline $\begin{array}{c}\text { Difference } \\
\text { Z-statistic Wilcoxon Mann Whitney }\end{array}$ & -1.258 & -1.583 & -0.167 & & \\
\hline
\end{tabular}

$*, * *, * * *$ significantly different from zero at the $\alpha=0.10,0.05$ and 0.01 level respectively (two-tailed)

Strong or weak legal protection is based on the mean of three variables which measure the quality of the legal system or enforcement, i.e. efficiency of the judicial system, rule of law and corruption index (La Porta, 1998). Hence France, Spain and the United Kingdom are classified as low legal protection, whereas Belgium, Finland and the Netherlands are classified as high legal protection. Strong or weak investor orientation is measured using factor-analysis on 4 country-specific institutional factors, i.e. La Porta et al. 's shareholder protection index, the source of a country's accounting principles, the extent to which financial and tax accounting rules are aligned and Hung 's (2001) accrual index (Peek et al., 2004). Hence, Belgium, Finland and France are classified as weakly investor oriented, while the Netherlands, Spain and the United Kingdom are classified as strongly investor oriented. 
Table 5

OLS Regressions on EMAgg

\begin{tabular}{|c|c|c|c|c|c|c|}
\hline \multirow[b]{2}{*}{ Variables (expected sign) } & \multicolumn{2}{|c|}{1} & \multicolumn{4}{|c|}{2} \\
\hline & $\begin{array}{l}\text { Coefficient } \\
\text { (t-statistic) }\end{array}$ & $\begin{array}{l}\text { Coefficient } \\
\text { (t-statistic) }\end{array}$ & $\begin{array}{l}\text { Coefficient } \\
\text { (t-statistic) }\end{array}$ & $\begin{array}{l}\text { T-test of } \\
\text { difference }\end{array}$ & $\begin{array}{l}\text { Coefficient } \\
\text { (t-statistic) }\end{array}$ & $\begin{array}{l}\text { T-test of } \\
\text { difference }\end{array}$ \\
\hline Intercept & $-14.796(-0.349)$ & $29.185(0.713)$ & $-27.660(-0.604)$ & & $19.542(0.408)$ & \\
\hline AUD & & & & & & \\
\hline B4 vs. Non-B4 (-) & $-8.574(-2.432) * *$ & $-38.533(-4.504) * * *$ & & & & \\
\hline B4 vs. Small (-) & & & $-10.469(-2.758)^{* * *}$ & $(-1.845)^{*}$ & $-34.077(-3.672)^{* * *}$ & $(-3.576)^{* * *}$ \\
\hline ST vs. Small (-) & & & $-3.309(-0.995)$ & & $3.977(0.371)$ & \\
\hline RLegal (-) & $-3.463(-3.936) * * *$ & $-5.735(-4.518) * * *$ & $-3.575(-4.169)^{* * *}$ & & $-5.253(-3.576)^{* * *}$ & \\
\hline ROrient (-) & $-2.189(-2.482)^{* *}$ & $-5.317(-4.633) * * *$ & $-2.420(-3.058)^{* * *}$ & & $-3.704(-2.985)^{* * *}$ & \\
\hline Interaction & & & & & & \\
\hline B4*RLegal (vs. non-B4)(-) & & $3.432(2.088) * *$ & & & & \\
\hline B4*ROrient (vs. non-B4)(-) & & $6.018(3.912)^{* * *}$ & & & & \\
\hline B4*RLegal (vs. Small)(-) & & & & & $3.097(1.676)^{*}$ & $(1.702)^{*}$ \\
\hline ST*RLegal (vs. Small)(-) & & & & & $-0.452(-0.205)$ & \\
\hline B4*ROrient (vs. Small)(-) & & & & & $4.635(2.680)^{* * *}$ & $(3.495)^{* * *}$ \\
\hline ST*ROrient (vs. Small)(-) & & & & & $-1.768(-0.972)$ & \\
\hline LNASSETS $_{\mathrm{t}}$ & $4.474(1.002)$ & $1.678(0.397)$ & 7.907 (1.632) & & $4.061(0.820)$ & \\
\hline $\mathrm{GROWTH}_{\mathrm{t}}$ & $-56.369(-1.290)$ & $-34.591(-0.845)$ & $-24.683(-0.638)$ & & $3.440(0.091)$ & \\
\hline $\mathrm{LEV}_{\mathrm{t}}$ & $66.049(3.252)^{* * *}$ & $59.684(3.135)^{* * *}$ & $33.988(1.767)^{*}$ & & 27.030 (1.449) & \\
\hline $\mathrm{ROA}_{\mathrm{t}}$ & $-47.828(-0.661)$ & $-69.321(-1.019)$ & $-56.779(-0.782)$ & & $-103.787(-1.466)$ & \\
\hline $\mathrm{N}$ & 113 & 113 & 145 & & 145 & \\
\hline $\mathrm{R}^{2}$ (Adjusted) & 0.399 & 0.481 & 0.357 & & 0.410 & \\
\hline $\mathrm{F}$ & $5.125 * * *$ & $6.193 * * *$ & $5.206^{* * *}$ & & $5.345^{* * *}$ & \\
\hline
\end{tabular}

$*, * *, * * *$ significantly different from zero at the $\alpha=0.10,0.05$ and 0.01 level respectively (two-tailed). Industry dummies, with Campbell 1 as industry of reference, are included but not reported.

$\mathrm{EM}_{\mathrm{Agg}}$ is an aggregate earnings management measure. AUD is a vector of audit dummies (B4: Company has a Big 4 auditor $=1$, else $=0$; $\mathrm{ST}$ : Company has a second-tier auditor $=1$, else $=0$ ). RLegal is a ranking index on legal protection, computed as the ranking of the mean of three legal variables which measure the quality of the legal system or enforcement, i.e. efficiency of the judicial system, rule of law and corruption index (La Porta, 1998). ROrient is a ranking index on a score measuring the investor orientation of a country's financial system as measured by Peek et al. (2004). LNASSETS ${ }_{t}$ is the natural logarithm of total assets in year t. GROWTH $H_{t}$ is the yearly percentage change in sales. LEV $_{t}$ is the ratio of total liabilities to total assets in year t. ROA is the yearly return on assets as measured by earnings divided by lagged total assets. 
Table 6

OLS Regressions on EM$_{\text {Discr }}$

\begin{tabular}{|c|c|c|c|c|c|c|}
\hline & \multicolumn{2}{|c|}{1} & \multicolumn{4}{|c|}{2} \\
\hline Variables (expected sign) & $\begin{array}{l}\text { Coefficient } \\
\text { (t-statistic) }\end{array}$ & $\begin{array}{l}\text { Coefficient } \\
\text { (t-statistic) }\end{array}$ & $\begin{array}{l}\text { Coefficient } \\
\text { (t-statistic) }\end{array}$ & $\begin{array}{l}\text { T-test of } \\
\text { difference }\end{array}$ & $\begin{array}{l}\text { Coefficient } \\
\text { (t-statistic) }\end{array}$ & T-test of difference \\
\hline Intercept & $104.017(2.140)^{* *}$ & $156.990(3.472)^{* * *}$ & 77.785 (1.515) & & $140.951(2.696)^{* * *}$ & \\
\hline \multicolumn{7}{|l|}{ AUD } \\
\hline B4 vs. Non-B4(-) & $4.165(1.030)$ & $-39.409(-4.169)^{*}$ & & & & \\
\hline B4 vs. Small (-) & & & $1.351(0.317)$ & $(0.866)$ & $-40.534(-4.004)^{* * *}$ & $(-2.260)^{* *}$ \\
\hline ST vs. Small (-) & & & $-2.419(-0.649)$ & & $-14.381(-1.230)$ & \\
\hline RLegal (-) & $-4.074(-4.036)^{* * *}$ & $-8.163(-5.819)^{* * *}$ & $-3.779(-3.930)^{* * *}$ & & $-8.032(-5.013)^{* * *}$ & \\
\hline ROrient (-) & $-1.309(-1.293)$ & $-5.049(-3.982)^{* * *}$ & $-1.366(-1.540)$ & & $-4.092(-3.023) * * *$ & \\
\hline \multicolumn{7}{|l|}{ Interaction } \\
\hline B4*RLegal (vs. non-B4)(-) & & $6.467(3.560 * * *$ & & & & \\
\hline B4*ROrient (vs. non-B4)(-) & & $7.228(4.252)^{* * *}$ & & & & \\
\hline \multicolumn{7}{|l|}{ B4*RLegal (vs. Small)(-) } \\
\hline \multirow{2}{*}{\multicolumn{7}{|c|}{$\begin{array}{l}\text { ST*RLegal (vs. Small)(-) } \\
\text { B4*ROrient (vs. Small)(-) }\end{array}$}} \\
\hline \multirow{2}{*}{\multicolumn{7}{|c|}{$\begin{array}{l}\text { B4*ROrient (vs. Small)(-) } \\
\text { ST*ROrient (vs. Small)(-) }\end{array}$}} \\
\hline & & & & & $0.696(0.350)$ & \\
\hline \multicolumn{7}{|l|}{ LNASSETS $_{\mathrm{t}}$} \\
\hline \multicolumn{7}{|c|}{$-5.864(-0.117))$} \\
\hline \multicolumn{7}{|c|}{$29.461(1.400)$} \\
\hline \multicolumn{7}{|c|}{$-227.311(-2.793)^{* * *}$} \\
\hline \multirow{3}{*}{$\begin{array}{l}\mathrm{N} \\
\mathrm{R}^{2} \text { (Adjusted) } \\
\mathrm{F}\end{array}$} & 113 & 113 & 145 & & 145 & \\
\hline & 0.289 & 0.431 & 0.269 & & 0.365 & \\
\hline & $3.531^{* * *}$ & $5.243 * * *$ & $3.789 * * *$ & & $4.599 * * *$ & \\
\hline \multicolumn{7}{|c|}{$\begin{array}{l}*, * *, * * * \\
\text { reported. }\end{array}$} \\
\hline \multicolumn{7}{|c|}{$\begin{array}{l}\mathrm{EM}_{\text {Discr }} \text { is an earnings discretion measure. AUD is a vector of audit dummies }(\mathrm{B} 4 \text { : Company has a Big } 4 \text { auditor }=1 \text {, else }=0 \text {; ST: Company has a second-tier auditor }=1 \text {, else }=0 \text { ). RLegal is a } \\
\text { ranking index on legal protection, computed as the ranking of the mean of three legal variables which measure the quality of the legal system or enforcement, i.e. efficiency of the judicia } \\
\text { system, rule of law and corruption index (La Porta, 1998). ROrient is a ranking index on a score measuring the investor orientation of a country's financial system as measured by Peek et al } \\
\text { (2004). LNASSETS }{ }_{t} \text { is the natural logarithm of total assets in year } t \text {. GROWTH } H_{t} \text { is the yearly percentage change in sales. } \text { LEV }_{t} \text { is the ratio of total liabilities to total assets in year t. ROA } A_{t} \text { is the } \\
\text { yearly return on assets as measured by earnings divided by lagged total assets. }\end{array}$} \\
\hline
\end{tabular}


Table 7

OLS Regressions on EM $_{\text {Smooth }}$

\begin{tabular}{|c|c|c|c|c|c|c|}
\hline & \multicolumn{2}{|r|}{1} & \multicolumn{4}{|c|}{2} \\
\hline Variables (expected sign) & $\begin{array}{l}\text { Coefficient } \\
\text { (t-statistic) }\end{array}$ & $\begin{array}{l}\text { Coefficient } \\
\text { (t-statistic) }\end{array}$ & $\begin{array}{l}\text { Coefficient } \\
\text { (t-statistic) }\end{array}$ & $\begin{array}{l}\text { T-test of } \\
\text { difference }\end{array}$ & $\begin{array}{l}\text { Coefficient } \\
\text { (t-statistic) }\end{array}$ & T-test of difference \\
\hline Intercept & $-133.609(-2.188)^{* *}$ & $-98.620(-1.572)$ & $-133.105(-1.992)^{* *}$ & & $-101.867(-1.410)$ & \\
\hline \multicolumn{7}{|l|}{ AUD } \\
\hline B4 vs. Non-B4 (-) & $-21.312(-4.196)^{* * *}$ & $-37.658(-2.871)^{* * *}$ & & & & \\
\hline B4 vs. Small (-) & & & $-22.289(-4.025) * * *$ & $(-3.195) * * *$ & $-27.620(-1.974)^{*}$ & $(-3.123)^{* * *}$ \\
\hline ST vs. Small (-) & & & $-4.199(-0.866)$ & & $22.336(1.382)$ & \\
\hline RLegal (-) & $-2.852(-2.250)^{* *}$ & $-3.307(-1.700)^{*}$ & $-3.372(-2.695 * * *$ & & $-2.474(-1.117)$ & \\
\hline ROrient (-) & $-3.069(-2.415)^{* *}$ & $-5.584(-3.174)^{* * *}$ & $-3.474(-3.009)^{* * *}$ & & $-3.316(-1.772)^{*}$ & \\
\hline \multicolumn{7}{|l|}{ Interaction } \\
\hline B4*RLegal (vs. non-B4)(-) & & $0.397(0.158)$ & & & & \\
\hline B4*ROrient (vs. non-B4)(-) & & $4.808(2.039)^{* *}$ & & & & \\
\hline \multicolumn{7}{|l|}{ B4*RLegal (vs. Small)(-) } \\
\hline \multirow{2}{*}{\multicolumn{7}{|c|}{$\begin{array}{l}\text { ST*RLegal (vs. Small)(-) } \\
\text { B4*ROrient (vs. Small)(-) }\end{array}$}} \\
\hline \multirow{2}{*}{\multicolumn{7}{|c|}{$\begin{array}{l}\text { B4*ROrient (vs. Small)(-) } \\
\text { ST*ROrient (vs. Small)(-) }\end{array}$}} \\
\hline \multirow{2}{*}{\multicolumn{7}{|c|}{$\begin{array}{l}\text { ST*ROrient (vs. Small)(-) } \\
\text { LNASSETS }_{\mathrm{t}}\end{array}$}} \\
\hline & & & & & & \\
\hline \multicolumn{7}{|c|}{$-106.874(-1.697)^{*}$} \\
\hline \multicolumn{7}{|c|}{$97.125(3.319)^{* * *}$} \\
\hline \multicolumn{7}{|c|}{$113.753(1.074)$} \\
\hline \multirow{3}{*}{$\begin{array}{l}\mathrm{N} \\
\mathrm{R}^{2} \text { (Adjusted) } \\
\mathrm{F} \\
\end{array}$} & 113 & 113 & 145 & & 145 & \\
\hline & 0.370 & 0.384 & 0.312 & & 0.326 & \\
\hline & $4.647 * * *$ & $4.493 * * *$ & $4.441^{* * *}$ & & $4.028 * * *$ & \\
\hline \multicolumn{7}{|c|}{$\begin{array}{l}*, * *, * * * \text { significantly different from zero at the } \alpha=0.10,0.05 \text { and } 0.01 \text { level respectively (two-tailed). Industry dummies, with Campbell } 1 \text { as industry of reference, are included but no } \\
\text { reported. }\end{array}$} \\
\hline \multicolumn{7}{|c|}{$\begin{array}{l}\mathrm{EM}_{\text {Smooth }} \text { is an earnings smoothing measure. AUD is a vector of audit dummies }(\mathrm{B} 4 \text { : Company has a Big } 4 \text { auditor }=1 \text {, else }=0 \text {; ST: Company has a second-tier auditor }=1 \text {, else }=0 \text { ). RLegal is } \\
\text { a ranking index on legal protection, computed as the ranking of the mean of three legal variables which measure the quality of the legal system or enforcement, i.e. efficiency of the judicia } \\
\text { system, rule of law and corruption index (La Porta, 1998). ROrient is a ranking index on a score measuring the investor orientation of a country's financial system as measured by Peek et al } \\
(2004) \text {. LNASSETS } \mathrm{t}_{\mathrm{t}} \text { is the natural logarithm of total assets in year } t \text {. GROWTH } \mathrm{H}_{\mathrm{t}} \text { is the yearly percentage change in sales. } \mathrm{LEV}_{\mathrm{t}} \text { is the ratio of total liabilities to total assets in year t. ROA } \mathrm{A}_{\mathrm{t}} \text { is the } \\
\text { yearly return on assets as measured by earnings divided by lagged total assets. }\end{array}$} \\
\hline
\end{tabular}

